\title{
A novel evaluation of genetic polymorphism in BCG adenitis
}

\author{
Maryam Hassanzad ${ }^{1}$, Poupak Farnia ${ }^{2,3}$, Sepideh Darougar ${ }^{4 *}$, Ali Akbar Velayati² \\ ${ }^{1}$ Pediatric Respiratory Diseases Research Center and ${ }^{2}$ Mycobacteriology Research Center, National Research Institute \\ of Tuberculosis and Lung Diseases (NRITLD), Shahid Beheshti University of Medical Sciences, Tehran; ${ }^{3}$ Department \\ of Biotechnology, School of Advanced Technology in Medicine, Shahid Beheshti University of Medical Sciences, \\ Tehran; ${ }^{4}$ Department of Pediatrics, Tehran Medical Sciences Branch, Islamic Azad University, Tehran, Iran. E-mail: \\ sepidehdarougar@yahoo.com \\ Received: 12th July 2017, Revised: 6th September 2017, 13th October 2017, Accepted: 27 th November 2017
}

SUMMARY: Hassanzad M, Farnia P, Darougar S, Velayati AA. A novel evaluation of genetic polymorphism in BCG adenitis. Turk J Pediatr 2019; 61: 466-470.

Bacillus Calmette-Guerin (BCG) is a live attenuated vaccine which has been used to prevent tuberculosis, according to the World Health Organization (WHO) recommendation in parts of the world with an incidence of tuberculosis infection more than $1 \%$. The incidence of BCG adverse reactions differs between regions with regional lymphadenitis as the most common presentation. The aim of this study was to detect the impact of polymorphisms causing BCG lymphadenitis in children receiving BCG vaccination at birth.

Eight healthy infants with BCG adenitis from 4 to 12 months old were enrolled. All these patients underwent a thorough physical examination, abdominopelvic ultrasound evaluation to detect distant lymphadenopathies and immunodeficiency screening tests for any possible underlying immunodeficiency disorders. Then genotyping for known mutations was performed using restriction fragments length polymorphism (PCR-RFLP) assays. Sequencing was performed for IL-12 R $\beta 1$, IFN- $\Upsilon$ receptor 1 , IL-10, TNF- $\alpha$ and P2X7.

The mean age of onset of the adenitis was 6.5 months. TNF-857, IL-12R $\beta 1$ 705, IL-10 1082, and IFN-Y- 56 single nucleotide polymorphisms (SNPs) were common in the children studied. The most frequent polymorphism found in the patients with BCG adenitis except one, was the P2X7 -762 polymorphism.

To conclude, these polymorphisms are more common in some ethnic populations but not others and make the genetic basis of immunity to BCG strains and the occurrence of post-BCG lymphadenitis in otherwise healthy children.

Key words: BCG, adenitis, immunization, genetic, polymorphism.

Bacillus Calmette-Guerin (BCG) is a live attenuated vaccine which has been used to prevent tuberculosis since 1921. The World Health Organization has recommended BCG immunization in parts of the world with an incidence of tuberculosis infection more than $1 \% .{ }^{1}$ Iranian healthcare system practices this vaccine by giving a single intradermal injection of $0.05 \mathrm{~mL}$ of bovis strain at left deltoid soon after birth. Although it is usually a safe vaccine, a number of complications can occur of which BCG adenitis is the most common. ${ }^{2}$ BCG adenitis is the development of ipsilateral regional lymph node enlargement usually the axillary lymph nodes after BCG vaccination when they reach a diameter greater than or equal to $1 \mathrm{~cm}$ and become a cause of concern for the parents. ${ }^{3}$ However supraclavicular and cervical lymph node(s) involvement may also occur. It typically develops 2 weeks to 6 months after immunization. ${ }^{3,4}$ The factors implicated in this event include the BCG 
strain, the age of the vaccinee, the injection technique and the genetic background of the recipients. $^{2-7}$ Cytokine polymorphisms are important genetic factors influencing the individual's susceptibility to BCG-adenitis and have been evaluated in recent studies. KamaliSarvestani et al. ${ }^{8}$ evaluated forty patients with BCG adenitis and concluded that IL10-592 C-to-T polymorphism lead to weaker immune response and hence bacterial burden and occurrence of lymphadenitis. Chen et al. ${ }^{9}$ found MBL polymorphisms associated with the susceptibility of tuberculosis and genegene interactions among them. Mosaad et al. ${ }^{10}$ reported that low producer IGN- $\Upsilon+874$ A/A genotype was associated with post-BCG lymphadenitis in children under 5 years of age.

The aim of this study was to determine the association of different polymorphisms in causing BCG lymphadenitis in children receiving $B C G$ vaccination at birth. Identifying genetic susceptibility to post-vaccination BCG-adenitis may be used as a diagnostic tool to prevent BCG vaccination in subsequent siblings with the same polymorphisms in the regions which BCG vaccine is recommended.

\section{Case Reports}

This was an observational study conducted at the National Research Institute of Tuberculosis and Lung Diseases (NRITLD) as a tertiary care center from 2014 to 2016. Eight healthy children with BCG adenitis based on clinical examination were included in the study. Eight age- and sex-matched healthy children were also selected. All the patients and control groups were Iranian. The ages of the patients were between 4 to twelve months. All the patients underwent chest X- Ray and abdominopelvic ultrasound for further evaluation in order to detect distant lymphadenopathies. They were also evaluated for any possible underlying immunodeficiency by performing immunodeficiency screening tests including serum immunoglobulin quantitation assay, lymphocyte flowcytometry and nitroblue tetrazolium test (NBT). A whole blood sample was taken for genomic DNA evaluation and polymorphism detection. Then they were clinically followed-up for any signs of later dissemination. In summary inclusion criteria for BCG adenitis in this study were: isolated axillary or supraclavicular lymph node enlargement, history of BCG vaccination on the ipsilateral arm, absence of local or systemic signs of inflammation, and normal immunity in clinical work- up. The study was designed to test the impact of polymorphisms causing BCG lymphadenitis in children receiving BCG vaccination at birth. Genotyping for known mutations was done using restriction fragments length polymorphism assays. ${ }^{11-14}$ Sequencing was performed for IL-12 R $\beta 1$, IFN- $\Upsilon$ receptor 1 , IL-10, TNF- $\alpha$ and P2X7. ${ }^{10,14-}$ ${ }^{17}$ Written informed consent had been obtained from the parents and the study was approved by the Ethics Committee of NRITLD, Shahid Beheshti University of Medical Sciences. Children presented with lymphadenitis were evaluated thoroughly. Table I is a summary of history, physical exam and clinical work-up of these children.

A total of 8 children with BCG adenitis (4 females and 4 males) were included in the study. The mean age of onset of the adenitis was 6.5 months. The study was designed to test the impact of probable polymorphisms causing BCG lymphadenitis in children receiving BCG vaccination at birth. Genotyping for known mutations was done using restriction fragments length polymorphism assays. Sequencing was performed for IL-12 R $\beta 1$, IFNYR 1, IL-10, TNF- $\alpha$ and P2X7. The results are summarized in Table II.

As shown in the above Figure 1, TNF-857, IL12Rß1 705, IL-10 1082, and IFN-Y- 56 SNPs are common in patients with BCG adenitis. The most frequent polymorphism found in all of the patients with BCG adenitis except one was the P2X7 -762 polymorphism.

\section{Discussion}

Tuberculosis is a major cause of mortality worldwide attributable to a single infectious agent. ${ }^{5}$ However, Mycobacterium tuberculosis does not always lead to disease obligatory. ${ }^{5}$ BCG vaccine has been used to prevent tuberculosis with a low incidence of adverse reactions. Among these complications, BCG lymphadenitis is the most common one depending on many factors, of which genetic 
Table I. Clinical and Pathological Features of the Four Previous Isolated Cases of VLBW Neonates with Perforated MD.

\begin{tabular}{|c|c|c|c|c|c|c|c|c|}
\hline $\mathrm{H} \& \mathrm{P}$ & Case 1 & Case 2 & Case 3 & Case 4 & Case 5 & Case 6 & Case 7 & Case 8 \\
\hline$\overline{\text { Sex }}$ & Male & Male & Male & Male & Female & Female & Female & Female \\
\hline $\begin{array}{l}\text { Age at } \\
\text { presentation (mo) }\end{array}$ & 4.5 & 5 & 7 & 6.5 & 11.5 & 4 & 5.5 & 8 \\
\hline $\begin{array}{l}\text { Duration after } \\
\text { vaccine (mo) }\end{array}$ & 3.5 & 4 & 7 & 5 & 11 & 3.5 & 5.5 & 8 \\
\hline $\begin{array}{l}\text { Appearance of } \\
\text { BCG vaccination } \\
\text { site }\end{array}$ & Ulcerated & Scar & Scar & Scar & Scar & Scar & Scar & Scar \\
\hline PPD (mm) & 8 & 7 & 8 & 9 & 7 & 5 & 6 & 8 \\
\hline CXR & Normal & Normal & Normal & Normal & Normal & Normal & Normal & Normal \\
\hline $\begin{array}{l}\text { Body Weight at } \\
\text { presentation }(\mathrm{Kg})\end{array}$ & 6 & 6.7 & 8.2 & 7.1 & 6 & 5.8 & 7.2 & 8.7 \\
\hline $\begin{array}{l}\text { Health status at } \\
\text { Presentation }\end{array}$ & Normal & Normal & Normal & Normal & Normal & Normal & Normal & Normal \\
\hline $\begin{array}{l}\text { Diameters of } \\
\text { lymph node }(\mathrm{cm})\end{array}$ & $5 \times 6$ & $6 \times 6$ & $7 \times 5.5$ & $8 \times 6$ & $7 \times 7$ & $5 \times 5$ & $6 \times 6$ & $5 \times 8$ \\
\hline $\begin{array}{l}\text { Immunodeficiency } \\
\text { Screening }\end{array}$ & Normal & Normal & Normal & Normal & Normal & Normal & Normal & Normal \\
\hline
\end{tabular}

CXR: Chest X-ray Mo: months, Kg: kilogram, Mm: millimeter, $\mathrm{Cm}=$ centimeter

Table I. Detected Mutations in Children with BCG Adenitis.

\begin{tabular}{|c|c|c|c|c|c|c|c|c|}
\hline Cases mutation & Case 1 & Case 2 & Case 3 & Case 4 & Case 5 & Case 6 & Case 7 & Case 8 \\
\hline IL-10 1082 & $\mathrm{~A} / \mathrm{A}$ & $\mathrm{A} / \mathrm{A}$ & $\mathrm{A} / \mathrm{A}$ & $\mathrm{A} / \mathrm{A}$ & $\begin{array}{c}\text { No } \\
\text { mutation }\end{array}$ & $\mathrm{A} / \mathrm{A}$ & $\mathrm{G} / \mathrm{G}$ & $\mathrm{G} / \mathrm{G}$ \\
\hline IL-10 819 & $\begin{array}{c}\text { No } \\
\text { mutation }\end{array}$ & $\begin{array}{c}\text { No } \\
\text { mutation }\end{array}$ & $\begin{array}{c}\text { No } \\
\text { mutation }\end{array}$ & $\mathrm{T} / \mathrm{T}$ & $\mathrm{C} / \mathrm{C}$ & $\mathrm{T} / \mathrm{C}$ & $\begin{array}{c}\text { No } \\
\text { mutation }\end{array}$ & $\begin{array}{c}\text { No } \\
\text { mutation }\end{array}$ \\
\hline IL-10 592 & $\begin{array}{c}\text { No } \\
\text { mutation }\end{array}$ & $\begin{array}{c}\text { No } \\
\text { mutation }\end{array}$ & $\begin{array}{c}\text { No } \\
\text { mutation }\end{array}$ & $\mathrm{A} / \mathrm{A}$ & $\mathrm{C} / \mathrm{C}$ & $\mathrm{C} / \mathrm{A}$ & $\begin{array}{c}\text { No } \\
\text { mutation }\end{array}$ & $\begin{array}{c}\text { No } \\
\text { mutation }\end{array}$ \\
\hline TNF-308 & $\mathrm{G} / \mathrm{A}$ & $\mathrm{G} / \mathrm{A}$ & $\mathrm{A} / \mathrm{A}$ & $\begin{array}{c}\text { No } \\
\text { mutation }\end{array}$ & $\begin{array}{c}\text { No } \\
\text { mutation }\end{array}$ & $\mathrm{G} / \mathrm{G}$ & $\mathrm{A} / \mathrm{A}$ & G/A \\
\hline TNF-857 & $\mathrm{C} / \mathrm{T}$ & $\begin{array}{c}\text { No } \\
\text { mutation }\end{array}$ & $\mathrm{T} / \mathrm{T}$ & $\mathrm{C} / \mathrm{T}$ & $\begin{array}{c}\text { No } \\
\text { mutation }\end{array}$ & $\begin{array}{c}\text { No } \\
\text { mutation }\end{array}$ & $\mathrm{T} / \mathrm{T}$ & $\mathrm{T} / \mathrm{T}$ \\
\hline IL-12R705 & $\mathrm{A} / \mathrm{G}$ & $\mathrm{A} / \mathrm{G}$ & $\mathrm{G} / \mathrm{G}$ & $\mathrm{A} / \mathrm{G}$ & $\begin{array}{c}\text { No } \\
\text { mutation }\end{array}$ & $\mathrm{A} / \mathrm{G}$ & $\mathrm{G} / \mathrm{G}$ & $\mathrm{G} / \mathrm{G}$ \\
\hline IFN-YR 56 & $\mathrm{C} / \mathrm{C}$ & $\mathrm{C} / \mathrm{T}$ & $\mathrm{C} / \mathrm{C}$ & $\mathrm{C} / \mathrm{T}$ & $\mathrm{T} / \mathrm{C}$ & $\begin{array}{c}\text { No } \\
\text { mutation }\end{array}$ & $\mathrm{C} / \mathrm{C}$ & $\mathrm{C} / \mathrm{C}$ \\
\hline IFN-YR 611 & $\mathrm{C} / \mathrm{T}$ & $\mathrm{C} / \mathrm{T}$ & $\mathrm{C} / \mathrm{T}$ & $\begin{array}{c}\text { No } \\
\text { mutation }\end{array}$ & $\mathrm{C} / \mathrm{T}$ & $\mathrm{C} / \mathrm{T}$ & $\mathrm{C} / \mathrm{T}$ & $\mathrm{C} / \mathrm{T}$ \\
\hline P2X7 762 & $\begin{array}{c}\text { No } \\
\text { mutation }\end{array}$ & $\mathrm{G} / \mathrm{G}$ & $\begin{array}{c}\text { No } \\
\text { mutation }\end{array}$ & $\begin{array}{c}\text { No } \\
\text { mutation }\end{array}$ & $\mathrm{G} / \mathrm{G}$ & $\mathrm{G} / \mathrm{G}$ & $\begin{array}{c}\text { No } \\
\text { mutation }\end{array}$ & $\begin{array}{c}\text { No } \\
\text { mutation }\end{array}$ \\
\hline
\end{tabular}

A: Adenine, C: Cytosine,G: Guanine, T: Thymine, IL: Interleukin,ILR:Interleukin Receptor, TNF: Tumor Necrosis Factor, IFN-YR: Interferon-Gamma Receptor 


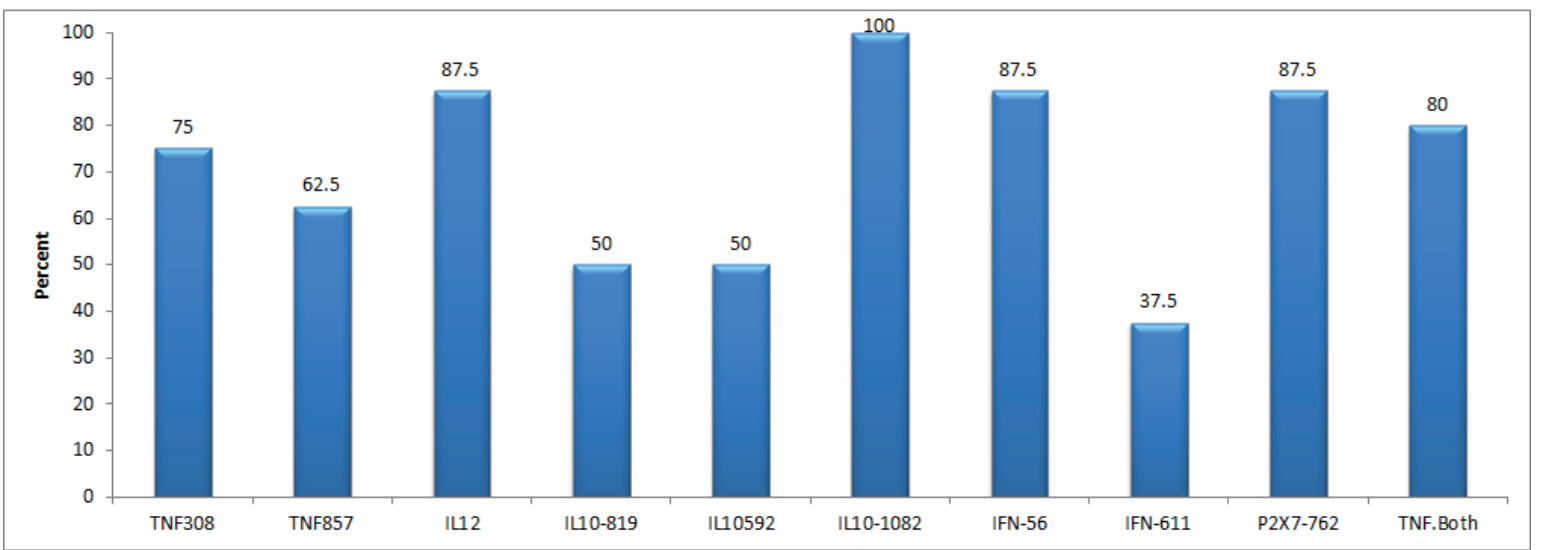

Fig. 1. A comparison of frequency of detected polymorphisms in pateients with BCG adenitis.

background of the recipient is highlighted in this study. Cytokines including TNF- $\alpha$, IL-10, and cell receptors such as IFN- $\Upsilon$, IL-12R $\beta 1$ and P2X7 have all been implicated in the regulation of the protective immune response elicited by BCG vaccine. ${ }^{11,13,14}$ Conversely, these components may also play important role in the formation of adenitis. ${ }^{3-5}$ The influence of polymorphisms in their genes and their effect on cytokine production is the subject of this study. Therefore, we have evaluated the polymorphism of TNF- $\alpha$, IL-10, IFN-YR, IL-12 $\beta 1 R$ and P2X7 in our otherwise healthy patients who developed BCG adenitis following BCG vaccination. ${ }^{17-19}$

IL-12R $\beta 1$ is a common receptor chain of the IL-12 and the IL-23 receptors. The lack of IL12 responses impairs the production of IFN-Y. According to van de Vosse et al. ${ }^{20}$, the IL$12 \mathrm{R} \beta 1$ polymorphism which we found in these children, is a mild deleterious mutation that does not induce a detectable immunological defect or overt clinical symptoms except regional lymphadenitis.

Polymorphisms in IFN- $\Upsilon$ receptor may alter the infectious outcome and result in tuberculous infection in some ethnic populations ${ }^{10}$ or in others with otherwise normal immune system may only cause post-BCG lymphadenitis.

IL-10 nucleotide polymorphisms (1082 A/G) have been associated with altered levels of this cytokine which may alter Th1/Th2 balance. ${ }^{10}$ Considering the intact immune system of these children, regional lymphadenopathy is the sole clinical presentation of this mutation. Tumor Necrosis Factor is considered as an important factor in host defense against intracellular bacterial infections such as Mycobacterium tuberculosis $^{6}$ due to its immunoregulatory properties in activation of macrophage and induction of pro-inflammatory responses. ${ }^{21}$ Our evaluation revealed one of these two polymorphisms in $62 \%-75 \%$ of our patients and both of them in $50 \%$ of the patients. According to the mentioned functions of TNF- $\alpha$ in control of infections, and also its role in inducing inflammatory signs, we have considered these two codons as possible loci of susceptibility for BCG adenitis in Iranian children.

P2X7 receptors are highly expressed on macrophages. Activation of P2X7 not only results in the induction of caspase cascade, but also activates phospholipase D (PLD). The major role of PLD is to promote the fusion of phagosome-lysosome which leads to the death of mycobacteria. ${ }^{19}$ Previously, several single nucleotide polymorphisms in P2X7 with a resultant reduction or loss of receptor function $^{22}$ have been identified. Maybe this polymorphism only leads to adenitis without significant mycobacterial infection in Iranian children.

We conclude that cytokine polymorphisms are associated with altered levels of secretion of certain cytokines. It appears that these polymorphisms are more common in some ethnic populations but not others, and make the genetic basis of immunity to BCG strains and the occurrence of post-BCG lymphadenitis in otherwise healthy children. Further investigations are essential in countries with BCG vaccination program to prevent these 
adverse effects in subsequent siblings of index children with BCG adenitis.

This project was supported by the Mycobacteriology Research Center, National Research Institute of Tuberculosis and Lung Diseases (NRITLD), Shahid Beheshti University of Medical Sciences, Tehran, Iran.

\section{REFERENCES}

1. Bukhari E, Alzahrani M, Alsubaie S, Alrabiaah A, Alzamil F. Bacillus Calmette-Guerin lymphadenitis: A 6-year experience in two Saudi hospitals. Indian J Pathol Microbiol 2012; 55: 202-205.

2. Parvaneh N, Pourakbari B, Daneshjoo K, Ashraf H, Salavati A, Mamishi S. Polymorphism in the first intron of interferon-gamma gene $(+874 \mathrm{~T} / \mathrm{A})$ in patients with BCG adenitis. Iranian J Publ Health 2009; 38: 12-16.

3. Elsidig N, Alshahrani D, Alshehri M, et al. Bacillus Calmette-Guérin vaccine related lymphadenitis in children: Management guidelines endorsed by the Saudi Pediatric Infectious Diseases Society (SPIDS). Int J Pediatr Adolesc Medi 2015; 2: 89-95.

4. Heraud D, Carr RD, McKee J, Dehority W. Nontuberculous mycobacterial adenitis outside of the head and neck region in children: a case report and systematic review of the literature. Int J Mycobacteriol 2016; 5: 351-353.

5. Stanford J, Stanford C. Mycobacteria and their world. Int J Mycobacteriol 2012; 1: 3-12.

6. Akdis $\mathrm{M}, \mathrm{Aab} \mathrm{A}$, Altunbulakli C, et al. Interleukins (from IL-1 to IL-38), interferons, transforming growth factor $\beta$, and TNF- $\alpha$ : Receptors, functions, and roles in diseases. J Allergy Clin Immunol 2016; 138: 984-1010.

7. Zhang $\mathrm{Z}$, Zhu $\mathrm{H}, \mathrm{Pu} \mathrm{X}$, et al. Association between tumor necrosis factor alpha-238G/a polymorphism and tuberculosis susceptibility: a meta-analysis study. BMC Infect Dis 2012; 12: 328.

8. Kamali-Sarvestani E, Gharesi-Fard B, Alborzi A. Cytokine gene polymorphism in BCG lymphadenopathy. Iran J Med Sci 2015; 27: 125-130.

9. Chen $\mathrm{M}$, Liang $\mathrm{Y}, \mathrm{Li} \mathrm{W}$, et al. Impact of $\mathrm{MBL}$ and MASP-2 gene polymorphism and its interaction on susceptibility to tuberculosis. BMC Infec Dis 2015; 15: 151 .

10. Mosaad Y, Soliman O, Tawhid ZE, Sherif DM. Interferon-gamma $+874 \mathrm{~T} / \mathrm{A}$ and interleukin-10-1082 $\mathrm{A} / \mathrm{G}$ single nucleotide polymorphism in Egyptian children with tuberculosis. Scand J Immunol 2010; 72: 358-364.
11. Elahi MM, Asotra K, Matata BM, Mastana SS. Tumor necrosis factor alpha-308 gene locus promoter polymorphism: an analysis of association with health and disease. Biochim Biophys Acta 2009; 1792: 163172.

12. Sandhya P, Danda S, Danda D, et al. Tumour necrosis factor (TNF)- $\alpha-308$ gene polymorphism in Indian patients with Takayasu's arteritis-A pilot study. Indian J Med Res 2013; 137: 749-752.

13. Wang Q, Zhan P, Qiu LX, Qian Q, Yu LK. TNF-308 gene polymorphism and tuberculosis susceptibility: a meta-analysis involving 18 studies. Mol Biol Rep 2012; 39: 3393-3400.

14. Selvaraj P, Sriram U, Mathan Kurian S, Reetha AM, Narayanan PR. Tumour necrosis factor alpha $(-238$ and-308) and beta gene polymorphisms in pulmonary tuberculosis: haplotype analysis with HLA-A, B and DR genes. Tuberculosis (Edinb) 2001; 81: 335-341.

15. Delgado JC, Baena A, Thim S, Goldfeld AE. Ethnicspecific genetic associations with pulmonary tuberculosis. J Infect Dis 2002; 186: 1463-1468.

16. Bakayev VV, Mohammadi F, Bahadori $\mathrm{M}$, et al. Arylamine $\mathrm{N}$-acetyltransferase 2 slow acetylator polymorphisms in unrelated Iranian individuals. Eur J Clin Pharmacol 2004; 60: 467-471.

17. Merza M, Farnia P, Anoosheh S, et al. The NRAMPI, VDR and TNF-alpha gene polymorphisms in Iranian tuberculosis patients: the study on host susceptibility. Braz J Infect Dis 2009; 13: 252-256.

18. Li CM, Campbell SJ, Kumararatne DS, Hill AVS, Lammas DA. Response heterogeneity of human macrophages to ATP is associated with $\mathrm{P} 2 \mathrm{X} 7$ receptor expression but not to polymorphisms in the P2RX7 promoter. FEBS Lett 2002; 531: 127-131.

19. Fernando SL, Saunders BM, Sluyter R, et al. A polymorphism in the P2X7 gene increases susceptibility to extrapulmonary tuberculosis. Am J Respir Crit Care Med 2007; 175: 360-366.

20. van de Vosse E, Haverkamp MH, Ramirez-Alejo N et al. IL-12 R $\beta 1$ deficiency: mutation update and description of the IL 12RB1 variation database. Hum Mutat 2013; 34: 1329-1339.

21. Anoosheh S, Farnia P, Kargar M. Association between TNF-alpha (-857) gene polymorphism and susceptibility to tuberculosis. Iran Red Crescent Med J 2011; 13: 243-248.

22. $\mathrm{Wu} \mathrm{J}, \mathrm{Lu} \mathrm{L}$, Zhang $\mathrm{L}$, et al. Single nucleotide polymorphisms in P2X7 gene are associated with serum immunoglobulin $G$ responses to Mycobacterium tuberculosis in tuberculosis patients. Dis Markers 2015; 2015: 671272. 